\title{
Laras concept and its triggers: A case study on garap of jineman Uler Kambang
}

\author{
Widodo, Victor Ganap, Soetarno \\ Postgraduate, Institut Seni Indonesia Yogyakarta, Indonesia \\ Received: November 11, 2016. Revised: January 23, 2017. Accepted: April 2, 2017
}

\begin{abstract}
Laras is one unresolved aesthetic concept and gendhing garap models as the triggers have not been identified yet either. This paper is a case study which discusses a case of jineman garap Uler Kambang pélog lima, the first winner of Sindhèn Idol contest 2012, which is considered to have the most qualified performance to meet laras criteria. The purpose of this research is to figure out the laras concept construction and identify the gendhing garap models as its triggers. Laras concept reconstruction within the aesthetic framework of Javanese karawitan and identification of gendhing garap model are discussed based on concept of garap in Javanese karawitan. This research uses a qualitative-descriptive method. The results show that laras is a beautiful, delicate, and deep karawitan sense containing elements of mat, lega, betah, adhem, ayem, tentrem, jinem, sengsem, and marem. The triggering gendhing garap models include: garap of leres, rempeg, greget-urip, and sarèh-sumèlèh.
\end{abstract}

Keywords: laras; gendhing; model of garap; Javanese karawitan

How to Cite: Widodo, Ganap, V., \& Soetarno. (2017). Laras concept and its triggers: A case study on garap of jineman Uler Kambang. Harmonia: Journal of Arts Research And Education, 17(1), 75-86. doi:http://dx.doi.org/10.15294/harmonia. v17i1.7805

\section{Introduction}

In this paper, laras is considered as one Javanese karawitan aesthetic sense. Javanese karawitan sense has an important position as the orientation and parameter of gendhing quality and aesthetic channel in obtaining their beautiful essence (Sedyawati, 2006, p. 128). The Javanese art sense is the culmination of aesthetic perception which unifies subjects and objects (Marianto, 2011, p. 154-156). One karawitan sense occupying the position is laras. Laras is frequently attached to gendhing which parts are made in a particular garap model following the characters, performance functions, and applicable garap rules. Howe- ver, the owners and actors are not in one linguistic understanding to comprehend the laras concept and feel its presence in gendhing. In a competition or contest for example, gendhing is commonly discussed at the end of contest and explicitly used as a quality benchmark of participants' masterpiece works to determine the winners and intensely proceed, yet eventually without solution similar to a Sindhèn Idol 2012 contest case which works on the compulsory material of Jineman Uler Kambang.

Uler Kambang is a name of the oldest classical Javanese karawitan of jineman musical composition which is still popular until now (Waridi, 2002, p. 126). It is selected as the compulsory garap material based on

\footnotetext{
${ }^{\triangle}$ Corresponding author: Jl. Parangtritis Km 6,5, Sewon, Bantul, Yogyakarta, Daerah Istimewa Yogyakarta 55188

E-mail: widodo_bsejati@yahoo.com
} 
the following considerations: (1) its composition is a classical popular gendhing vocabular; (2) its sense is based on prenès and kenès, yet contains glorious and dignified elements favoured by many people; (3) the performance duration is relatively short; and (4) the sindhènan vocal garap is highly emphasized. According to the strength of performance sense, the Garap sindhenan Jineman Uler Kambang Pélog Lima is eventually performed by one of the finalists, Lina Rohmiyati from Wonogiri, Central Java who is supported by the professional karawitan players from several prominent gamelan group members from Semarang, is decided as the first winner among the other nine finalists who have also performed the same sindhènan gendhing vocal, yet followed with different laras and pathêt. Sindhenan is a vocal material containing ricikan garap with elements processed and translated with musical language (Budiarti, 2013).

Laras as a rare aesthetic sense is discussed by various karawitan researchers. There are many discussions made but mostly in the context of sléndro-pélog and only within its tones. Supanggah (2002, p. 86 ) in Bothékan Karawitan book I briefly defines laras as an aesthetic sense but its relationship formed with gendhing garap is not further discussed, similarly to Sumarsam 1992 , p. 1) who starts his dissertation by quoting tembang texts containing the word laras as one karawitan aesthetic sense.

Soetarno (2007, p. 13) states that Javanese Karawitan was born from a long searching process symbolically expressed through a vocal medium with laras léndro dan pélog. The performance function is not only intended to meet the entertainment purposes but also social, moral, cultural, and spiritual senses. Javanese gendhing has various basic senses and performance functions (Benamou, 1998, p. 129-134). The disclosure of various basic gendhing senses is made through works, balungan gendhing interpretations, choices, and implementations of vocabular techniques and playing patterns on gendhing parts based on the composition characters and performance functions. When the work is broken, the effort to express the basic sense and to achieve the essence of its beauty fails, as Sultan Agung said in the following Serat Sastra Gendhing.

Pramila gendhing yèn bubrah
Gugur sembaé mring Widdhi
Batal wasesaning salat
Tanpa gawé ulah gendhing
Déné ingaran ulah
Tukirèng swara linuhung
Amuji asmaning Dat
Swara saking osik wadi
Osik mulya wentaring cipta surasa
Translation
when gendhing is broken
the worship to God is broken as well
the power of worship is void
Gendhing processes are useless
it is called processes
due to the glorious vocal
to praise the God's names
voices of the secret movements
the dignified ones which create ideas
and senses

Work in Javanese karawitan refers to a creative and systemic musical work consisting of several interconnected and supportive stages to realize the qualified karawitan work. Work also means doing or making things into materials (Supanggah, 2009; Perlman, 1993). The concept contains several elements covering gendhing and balungan gendhing as the material works; pengrawit, wiraswara, and waranggana as the composers; Gamelan as the expressing means; vocabular technique, cengkok, and wiled as the working devices; the authority of people, institutions, social functions and musical services as the work determinants; while the physical and psychological conditions of karawitan musicians and external conditions are situational and accidental as the work consideration.

Gendhing is a Javanese karawitan musical composition in the forms of sampak, srepeg, lancaran, gangsaran, ayak-ayak, kemuda, ketawang, ladrang, jineman, ketawanggendhing, kethuk 2 kerep, kethuk 2 arang, kethuk 4 kerep, kethuk 4 arang, kethuk 8 kerep and kethuk 16 kerep; as well as pamijen (Rustopo, 2000, p. 34). In particular, gendhing 
means karawitan musical compositions in the forms of kethuk 2 kerep and other bigger ones. Jineman is a particular gendhing form, while balungan gendhing is as an abstraction form of song composition made based on the flows of the vocal song which part numbers and lengths are different for each composition.

Gendhing has the elements of irama (rhythm), laya, laras, pathêt, and dynamics. The work refers to the structure and composition of balunngan gendhing tones, composition characters, and performance functions. Irama concept is related to tempo gradations as well as ricikan and vocal playing contents. The gradual gendhing tempo results in the widened and narrowed beating distance between sabetan $b a-$ lungan. Those spaces are filled with ricikan and peking work playing in two folds increased or decreased number of beating. Javanese karawitan has five irama gradations covering lancer symbolized with $1 / 1$, tanggung $1 / 2$, dadi $1 / 4$, wiled $1 / 8$, and rangkep work. Symbol 1/1 shows the number of $p e-$ king beating on each sabetan balungan gendhing and the symbolic meaning of the other irama gradations (Martapangrawit, 1975, p. 2). Laya is gendhing speed at the same irama gradations, including: laya tamban or slow, laya sedheng or medium, and laya seseg or fast (Supanggah, 2002, p. 123). Laras as the gendhing musical element means that sléndro-pélog musical scales and tones contained within that are written in the form Nut Kepatihan in numeric symbols called titilaras (Sumarsam, 2003, p. 155-161). Pathet is the sèlè sense atmosphere on gendhing song lyrics made by the phase combinations of raising, lowering, gantungan, ageng tengah, and alit tones (Hastanto, 2009). Dynamics refers to various and proportionate works at all musical elements.

Most ricikan gamelan are in the forms pencon and plates made of the finest bronze metal. Ricikan pencon includes: penembung, bonang barung, bonang penerus, kenong, kethuk, kempyang, kempul, gong, engkuk, and kemong; ricikan plates include: gendèr barung, gendèr penerus, slenthem, demung, saron, peking, and gambang; other ricikan forms: rebab, kendang, bedhug, siter, clempung, suling, kemanak, gong beri, and kecer. Due to its musical roles, when working on gendhing, ricikan gamelan is divided into three: (1) balungan, that is, ricikan played close to balungan tone compositions including: slenthem, demung, saron, peking, and penembung; (2) work, that is, ricikan played by working on balungan gendhing, including: ricikan garap ngajeng (front): kendang, rebab, gendèr barung, bonang barung, sindhè, and ricikan garap wingking (back): gendèr penerus, gambang, siter, clempung, suling, bonang penerus, and gérong; and (3) structural, that is, ricikan which playing forms gendhing construction structures, including: kethuk, kenong, kempul, gong, engkuk, kemong, kemanak, and kecer (Supanggah, 2002, p. 71). Gamelan quality is determined by its materials, shapes, and laras sounds which have various interval patterns called embat (Hastanto, 2009, p. 22).

Metal ricikan is played by beating it with the beating device called tabuh; Rebab is swiped with rangkung; flute is blown; sitar and clempung are plucked; and kendang is beaten with palms and fingers. Some ricikan have special vocabular playing techniques: gemakan, kecekan, and genjotan on ricikan balungan; besutan, plurutan, sendhal pancing, kadhal mènèk, ngicrik on rebab; and mbalung, samparan, sarugan, pipilan, genukan, ukelan, gugukan, umbaran, pêthêtan on gendèr barung. Céngkok is also called sekaran, kembangan or playing pattern, that is, tone and rhythm configuration in certain length unit. Its implementation on gendhing garap has been given musical ornamentation called wiled. Gendèr barung has the most various céngkok vocabulars, namely: éla-élo, dualolo, jarik kawung, ayu kuning, kacaryan, ora butuh, tumurun, kutuk kuning, dhebyang-dhebyung, puthut gelut, puthut semèdi, gantungan, nduduk, rambatan, and ya surakka. Céngkok-céngkok is also called adapted by rebab, gambang, siter, clempung, and gendèr penerus. Other ricikan also have céngkok vocabulars, namely: milah, mipil, gembyang, imbal-sekaran, and klénangan on bonang barung; pinjalan, kinthilan, imbalan, nyacah, 
and pancer on ricikan balungan; and kendangan on gendhing shape with kendang bem or combination kendang bem and ketipung, kosek with kendang sabet, and kendang ciblon on kendang (Sukamso, 1992, p. 54).

Work in gendhing parts results in its models. Those using on gendhing determine karawitan senses, including laras. This type of aesthetic sense arises from the particular model implementation based on balungan gendhing tone structures and arrangements, composition characters, performance functions, and the applicable working rules. However, laras as an aesthetical concept, abstract idea dealing with karawitan beauty with certain characteristics, has been unresolved (Alfian, 2003, p. 1-3), as well as gendhing garap models as the triggers. Those problems are then discussed through a case study of Jineman Uler Kambang Laras Pélog Pathêt Lima, the first champion of Sindhèn Idol contest 2012 which performance is considered meeting laras criteria. These gendhing garap elements are discussed to figure out the construction of laras concept and gendhing models as its triggers.

\section{Method}

The object of this research is the $G a$ rap of Jineman Uler Kambang Pélog Lima as the first winner of Sindhèn Idol contest 2012. Sindhènan vocal performed by Lina Rohmiyati while ricikan gamelan is played by the collaboration of some karawitan professional musicians from Semarang, Central Java: Karawitan group of Sekar Dhomas Semarang, Suka Raras Semarang, and Studio RRI Semarang.

Research data are in the form of information about laras elements as the Javanese karawitan aesthetic sense and various aspects of gendhing garap models as the triggers. The first data are collected through literature sources and karawitan practitioners who are directly involved in gendhing garap and as appreciators, while the second ones are contained within the direct performance of Jineman Uler Kambang, Pélog Lima as well as in the audiovisual recording documents. The literature data sources are collected from literature studies; observation directly conducted in karawitan concert; document recording studies are made through the recording media; and respondent interviews are employed to gather the required data.

Data are verified using triangulation techniques to ensure its validity. Valid data are identified based on the problem solving needs which are classified into two groups: data of laras elements and aspects of work models as the triggers. The data are first analysed in the framework of Javanese karawitan aesthetics to figure out its conceptual formula, while the second ones are discussed in the framework of Javanese karawitan working concept to figure out the work model characteristics as laras triggers. The research processes and results are then descriptively explained.

\section{Results and Discussion}

\section{Description of sindhènan Vocal Work}

Sindhènan work involves vocal technique, céngkok and wiled selection and application, as well as the use of cakepan wangsalan, parikan, and abon-abon on gendhing sections. Jineman Uler Kambang vocal consists of several parts: (1) buka celuk, that is, short vocal song performed by a single pesindhèn to start gendhing; (2) sindhènan wangsalan, that is, céngkok sindhènan using wangsalan text applied on song lyric of ulian or sèlèh; (3) sindhènan parikan, that is, sindhènan céngkok vocal using parikan texts; (4) sindhènan abon-abon or isen-isen, that is, short céngkok sindhènan with abon-abon texts; and (5) sindhènan andhegan, that is, sindhènan vocal performed in the middle when gendhing is stopped as the bridge to the next gendhing section.

The above sindhènan vocal parts are found in the Garap of Jineman Uler Kambang sléndro pathêt sanga, sléndro pathêt manyura, pélog pathêt lima, pélog pathêt nem or nyamat, and pélog pathêt barang. In broad, the vocal Garap sindhènan Jineman Uler Kambang, Pé$\log$ Lima performed by the first winner of Sindhèn Idol contest 2012 is presented as in Figure 1. 


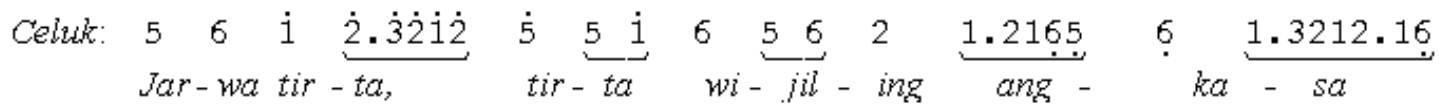

\section{A. Irama dadi}

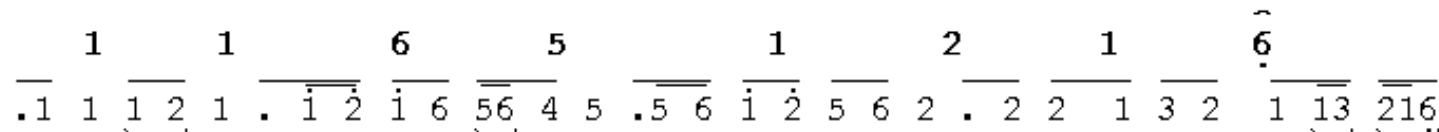

$$
\begin{aligned}
& \text { Sa-puk ru-kun - ru-kun ka-ro kom-ca-né Ja la-li lo masko-we, go-tong ro-pongnya-mbut ga-wé } \\
& \begin{array}{lllllllll}
2 & 4 & 5 & 6 & 5 & 4 & 2 & 1
\end{array}
\end{aligned}
$$

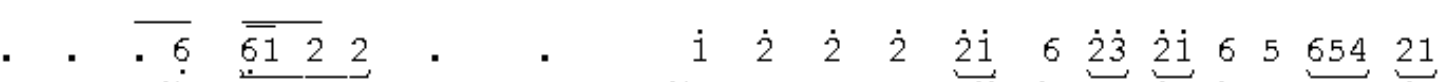

$$
\begin{aligned}
& \text { Ya }
\end{aligned}
$$

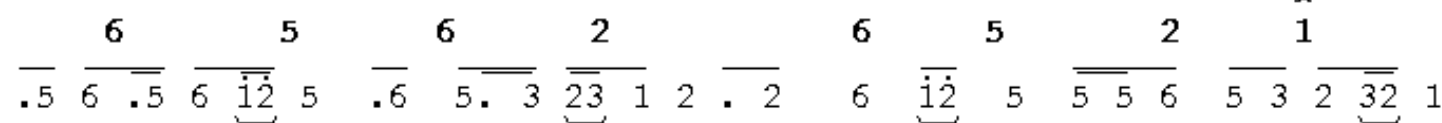

$$
\begin{aligned}
& \begin{array}{llllllll}
3 & 2 & 1 & 6 & 2 & 1 & 6 & \hat{5}
\end{array} \\
& \begin{array}{lllll}
2 & 5 & 2 & (1)
\end{array}
\end{aligned}
$$

Pan-ca Si-la dha-saring na- griu-ta - ma

B. Garap Rangkep

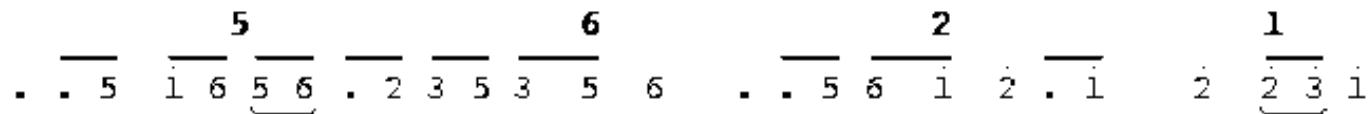

$H a-b a h o-\overline{r a}-p a-h a-j u n d-r g i n g \quad a-j u$ na-nging ngge-get a -ké

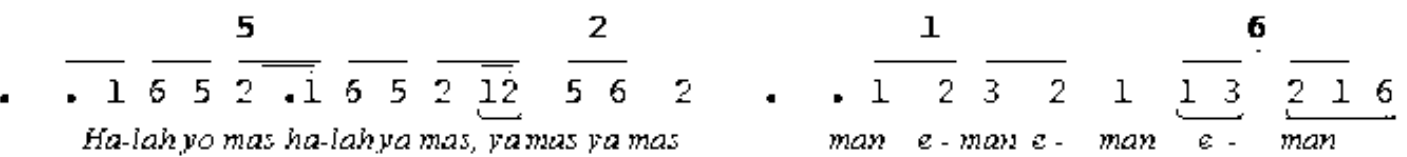

$$
\begin{array}{lllll}
2 & 4 & 5 & 6
\end{array}
$$

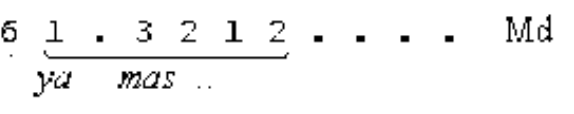

1

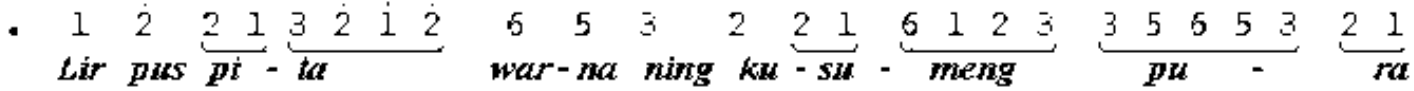

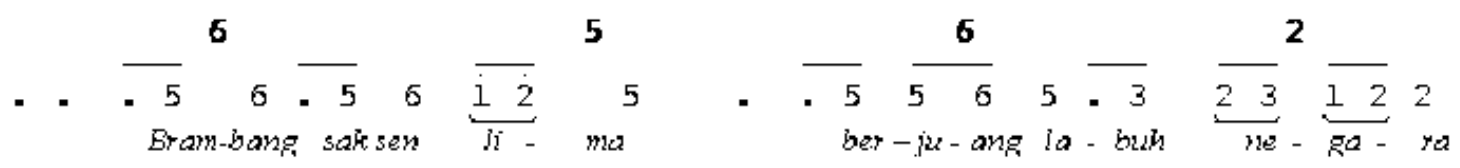
65

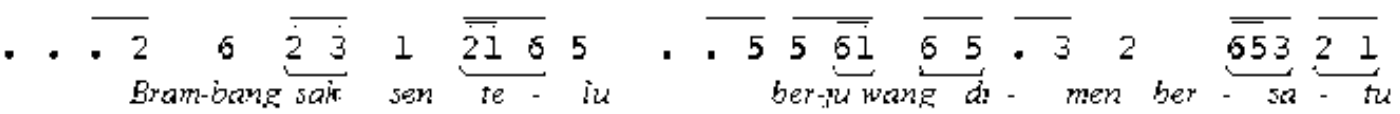
3 2 1

6

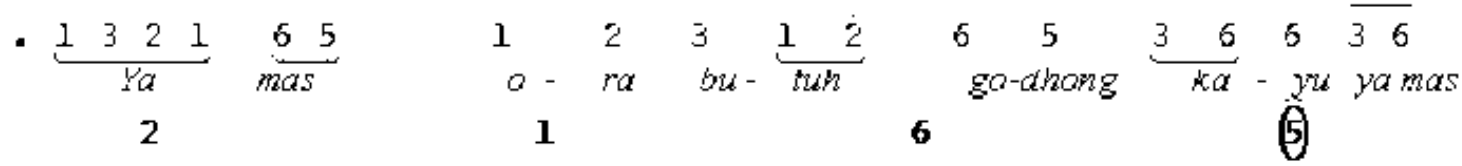

Figure 1. Garap of Jineman Uler Kambang 


\section{Cakepan}

Cakepan is a vocal song lyric. The above sindhènan vocal uses cakepan wangsalan, parikan, and abon-abon used in sindhènan vocal. Wangsalan is a literary work in the form of puzzles which questions and answers are implicitly expressed. Wangsalan is also frequently used in Cirebon classical tarling songs (Suharto, 2016). In wangsalan, the questions and answers may be found after the formation of its phrases are analyzed based on its meaning and relation. The example of wangsalan analysis is as follows.

Kawi lima putra priya Dahywang Durna Pancasila dasaré Nagri utama

Jarwa tirta, tirta wijiling angkasa

Nyenyuwuna, mrih kasembadaning sedya

Translation

Kawi (language) (for the word) five, is the son (name) of Resi Druna

Pancasila (becomes) the (main) state principle

The term (to mention) water, is the water (which) falls from the sky

Pray, that your wishes may come true

The first wangsalan consist of two phrases: kawi lima putra priya Dahywang Durna; and Pancasila dasaré Nagri utama. The first phrase is the question while the second is the answer. The explicit question is what Kawi language for the word five is. The answer is mentioned in the second phrase, that is, panca as a part of the word Pancasila. The second explicit question is what the name of Resi Druna's son is. The answer is Aswatama, tama is a part of the word of utama mentioned in the answer phase. The second wangsalan consists of two phrases: jarwa tirta tirta wijiling angkasa; and nyenyuwuna mrih kasembadaning sedya. There are two question phases covering jarwa tirta and tirta wijiling angkasa. The answer to the first question of jarwa tirta is banyu (water), the word part of nyu is derived from the word nyenyuwuna. The answer to the second question phase is udan (rain), as the word part of kasembadan. Parikan is pantun literary work com- posing of two or four regular rhymes. The last syllable of the first and the third phase as well as the second and the fourth phrase (if parikan consisting of four phrases), or the first and second phrase (if parikan consisting of two phrases) have similar sounds, as follows.
Sayuk rukun, rukun karo kancané Gotong royong nyambut-nyambut gawé Kinclong-kinclong, kinclong guwayané Mubyar murub, mancorong katon tejané Brambang sak sèn lima
Berjuang labuh negara
Brambang sak sèn telu
Berjuang dimen bersatu
Translation
Unity in harmony with companions
Mutually working cooperation
Pure and obviously clear the water Glowing, shining, and illuniminting aura is shown
One cent (gets) five red onions
Fighting for the state and the nation
One cent (gets) three red onions
Fighting for the sake of unity of the na- tion

Abon-abon or isèn-isèn is short texts which sometimes are meaningless or the meanings are not taken into account. Sindhènan abon-abon in gendhing is performed to fulfill the vacant space before or after the main vocal song (Waridi, 2002, p. 130). Abon-abon texts in sindhènan vocal above are: ya mas, ya rama ya rama-ramané dhéwé, ha-lah yo mas, ya mas ya mas, and man-émanéman-éman.

\section{Ricikan garap}

Jineman Uler Kambang performance involves kendang, gendèr barung, gendèr penerus, gambang, suling, kenong, kethukkempyang, gong, clempung, siter, and gérong. Gender barung starts the performance of grambyangan playing as laras and pathêt guidance for pesindhèn to innitiate buka celuk tones. At Jineman Uler Kambang above, gendèr barung plays grambyangan pélog pathêt lima to guide buka celuk tones in laras of pélog pathêt lima. After the flows of rhythmic song passes through tone five, kendang responds it with kendangan patterns 
of nampani buka irama dadi using kendang ciblon. At the second ketegan, ricikan garap group simultaneously plays gendhing together. At the eighth gatra which is ended with panunggal or siji tone, there is a rhythmic transition from dadi to rangkep initiated with the slowing down tempo. At the first gatra rangkep, the performance of mandheg is continued with single sindhènan as the bridge to the following gendhing part section until suwuk.

Ricikan garap interpretation refers to the structure and composition of balungan gendhing tones from the abstraction of the flows of the vocal song as in Figure 2.

Since buka celuk, kendang has welcomed it with pematut pattern. This pattern is played along gendhing playing interrupted by kengser pattern in the middle of the first gatra of the second kenong, and ngaplak pattern in the third kenong of the second gatra. When approaching gong panunggal, tempo is slowing down shifting to rangkep work. Ngaplak pattern is also performed in rangkep work before the final andhengan of the first gatra of the second kenongan. Céngkok-céngkok gendèr barung implemented to gendhing sections is followed by ricikan song work, namely: a quarter of sèlèh 6 to respond buka celuk, followed by half of gantungan 1 tumurun 5 , puthut gelut, dhebyang-dhebyung, dualolo 6, tumurun 5, and kkg1. Slenthem plays balungan gendhing tone composition, while kenong plays its tones at the end of kenongan based on balungan gendhing tones except panunggal tones are played five to build a harmonic sound, kethuk-kempyang plays a pattern, such as in ketawang ladrang, gong gedhé giving a strong sèlèh impression at the end of the fourth kenongan, and at the fifth gatra with gong of suwukan panunggul, while gérong plays imbal keplok, senggakan, and alok.

\section{Discussion}

Almost all Javanese karawitan players enjoy their performance either directly or through audio visual recording document including that uploaded by Suharto (2013) in Youtube media. Some media acessors generally appreciate that by revealing their compliments, such as "duh...nggarai ati adem, suaramu waduh-waduh mak nyes, serak-serak penak lan laras banget, gayeng tenan, rasane tekan ati, jan mat tenan, manteb banget, nyamleng tenan, gawe ademe ati, marem, sampai ngantuk. The expressions of various aesthetic words are the proofs of individuals who enjoy the beauty of the show performance. Those expressions are due to the arising emotions when enjoying the music, because music can express emotions (Juslin, 2013). This video has been viewed by more than 40,000 people and of those, 161 people show that they enjoy the video by giving their thumbs up. In the discussions of board of jury panel to determine the championships, some members feel that their performance mengkorokaké githok or make their hair stands and ends, the predicate given on something, including the extraordinary beautiful objects which provide deep impression. From vocal sindhènan point of view, the beauty of performance is influenced by many factors: first, pesindhèn basic voice is more astonishing with kenès but gentle voice type, strong character, subtle and complex gregel, soft vibration, and broad ambitus. That basic tone has a chance to voice more complicated vocal flows, broad ambitus, and various musical characters.

Second, the tones on laras sléndro and pélog are sophisticatedly mastered. Darsono, a Javanese karawitan vocal expert from ISI Surakarta as the chairman of board of jury panel in the contest, asserts that the flows of the vocal song may be performed in pleng when the vocalist has mastered

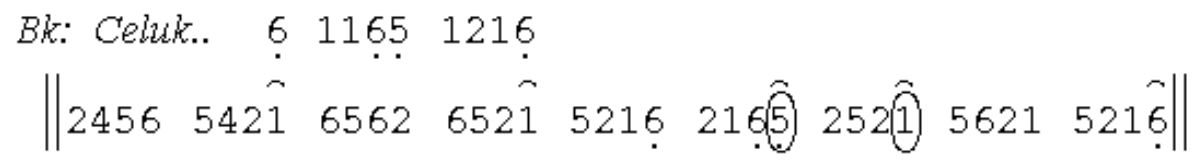

Figure 2. Balungan gendhing, result of abstraction 
laras sléndro-pélog. The pleng concept referring to the tone sounding of the flows of the vocal song is relatively accurate, not exceeding the limits of laras sléndro and pélog tone frequency tolerance. No matter how complicated wiled to céngkok vocal song, it is not meaningful if one or more tones are not pleng or bléro, sasap. The tone arrangement in wiled and céngkok-céngkok of sindhènan vocal above is expressed in pleng that the performance is pleasant to be heard and felt.

Thirdly, céngkok and wiled variously use and their implementation to the proper gendhing parts, not nglèwèr nor nungkak. Nyi Supadmi, Javanese karawitan sindhèn master from Surakarta as the member of board of Jury panel, explains that nglèwèr shows sèlè the flows of the vocal song is far behind sèlè balungan gendhing, while nungkak is far forefront. From this perspective, sindhènan vocal work above is considered the most qualified one. Céngkok dan wiled in several sèlèh panunggul tones are different, as well as the other sèlèh tones with the relatively accurate implementation which results in dynamic musical impression, unison, and integrated manners in the dynamic integrity of gendhing garap.

Fourth, cakepan is correctly, clearly, and firmly expressed. Vocal text pronunciation unclearness may lead to multiple interpretations of meaning. Thus, the work is considered a fatal error which greatly reduces the esthetic value of the performance. Vocal text expression correctly, clearly, and firmly shows that the vocalist understands Javanese language, text meaning, and how to pronounce it.

Fifth, gendhing characters and their parts are strongly expressed through vocal work model performed with full concentration, spirit, and understanding, in addition to menep, sarèh, and sumèlèh, patient, not in hurry inspired by the characters of gendhing composition. The vocal work performance greatly provides the spirit to gendhing parts that its performance is greget-urip, dynamic, energetic, and alive.

Sixth, pesindhèn performance upholds the aesthetic values and the applicable cul- tures. Pesindhèn appears in timpuh, a seated position with both folded hands over his thigh in a calm and dignified manner. A complete Javanese traditional cloth is worn to make pesindhèn look stunning based on the applicable aesthetic and cultural norms in Javanese karawitan.

Some musical and cultural aspects above are taken into consideration by the board of jury panel to decide the winners based on the criteria of leres, rempeg, and laras. Lina Rohmiyati is named the first winner because she is considered as the most qualified one meeting the criteria. However, its beauty may not be realized without the supports of ricikan garap and gendhing musical elements. In terms of ricikan engagement, its technical work, playing patterns, and dynamic, the supporting ricikan gamelan playing is expressed correctly, clearly and firmly in the evenly, balance, unison, and integrated composition dynamically under the lead of sindhènan song and kendangan dynamics which result in depth and holistically striking karawitan sense. The manifestation of karawitan sense is also due to the support of Kyi Cakra Kembang's gamelan devices belonging to Semarang State University which laras and materials are highly qualified.

\section{Laras Concept: A Study on Jineman Uler Kam- bang Pelog Lima}

The results of the research on Jineman Uler Kambang Pelog Lima are supported by the views of the research respondents through the findings of some keywords on laras concepts: (1) laras is a kind of sense, atmosphere, or impression of beautiful, delicate, comfortable, deep, and holistic containing the element of mat, lega, betah, adhem, ayem, tentrem, jinem, sengsem, and marem; (2) the triggering events contain many elements with specific characters, roles, and functions; (3) these elements interact each other to realize the common goals; (4) interactions between elements run dynamically, truly, fairly, evenly, in balance, unison, and integrated manners within one integrated purpose made at the atmosphere of togetherness, mutual respect, 
and helping each other to follow the applicable norms; And (5) its interaction models form the perfect balance centers called the harmonic points as the sources from which laras occurs. In Javanese karawitan, that event is called klenèngan or karawitan concert with its activities in the forms of a gendhing garap processes. Laras concept is schematically made as follows.

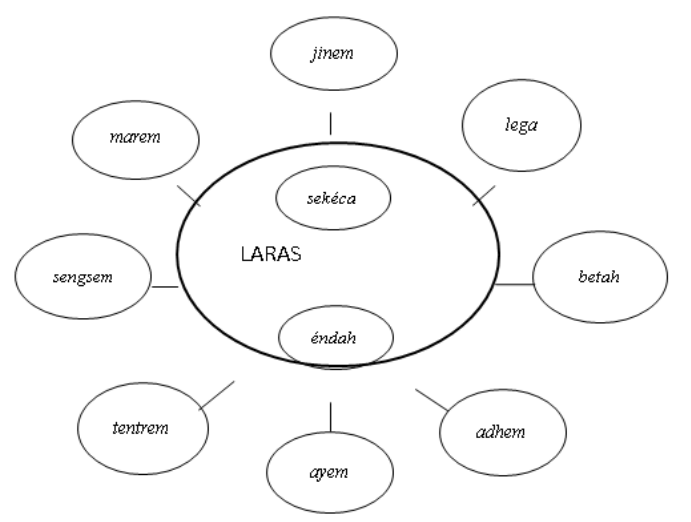

Figure 3. Laras Concept

The keywords appearing in Figure 2 are similar with the viewers' comments on a youtube video uploaded by a youtuber, Suharto (2013) and that has been watched by more than 40,000 viewers. The expressions made by the observers and viewers are considered as conceptions. Meanwhile, conception is a particular meaning given to a term by particular individuals. Based on these conceptions, a concept may be created. Thus, concept is an abstract notion based on a set of conceptions or a sharpened conception (Rohidi, 2011, p.126) as concept is also considered as an abstract and general idea of a particular case. Concept is what exists in the mind as a representation (as of something comprehended) or as a formulation (as of a plan), concept may apply to the idea formed by consideration of instances of a species or genus or, more broadly, to any idea of what a thing ought to be (Merrieam-Webster, n.d.). thus, Laras concept is made after understanding the conceptions, such as mat, lega, betah, adhem, ayem, tentrem, jinem, sengsem, marem.

\section{Gendhing garap Model Triggering Laras}

Laras which concept has been defined does not suddenly appear. Some gendhing garap models as laras triggers are leres, rempeg, greget-urip; and sarè-sumèlèh. Literally, leres means true, accurate, appropriate (Widada et al., 2000, p. 59 \& 590). The concept in gendhing garap refers to the selection and implementation of vocabular techniques, patterns, and wiled of true or precise playing based on balungan gendhing's structures and song flow patterns, character compositions, and performance functions based on the applicable work patterns in Javanese karawitan.

Literally, the word rempeg means unison, simultaneous, and dense (Widada et al., 2000, p. 667). Rempeg in gendhing performance refers to the work in gendhing elements which are dynamic, balance, evenly, unison and in integrated manners with the unity of work idea. Dynamic impression appears from various works; balance shows the playfulness of ricikan as well as the clear and proportional vocal: evenly means all gendhing elements are touched by the work, there is no dominant or dominated element: unison is playing or céngkok and wiled patterns in gendhing parts based on each musical tasks following the composition types and shapes as well as balungan gendhing tone composition.

Greget refers to the disclosure of gendhing garap models which are full of concentration, spirit, strength, and understanding shown by the characters of composition parts which enliven gendhing spirit or soul and its parts arising urip (alive) impression meeting the basic sense of gendhing.

Sarèh-sumèlèh refers to the work expressions which are quietly, patiently, unhurriedly made based on the mastery of the mature work device aspects indicating that the competence of karawitan work composers is greatly qualified. Schematically, gendhing garap models as the triggers of laras are as follows. 


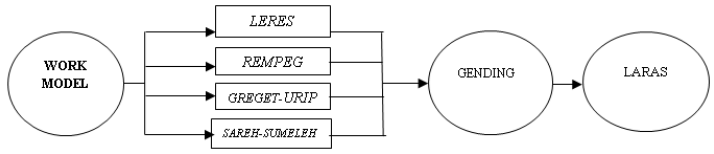

Figure 4. The Triggering Aspects of Laras

Laras in gendhing performance may not be realized only from one work aspect. Some aspects are closely related and support each other to realize the karawitan gendhing as a whole. Laras sense in Jineman Uler kambang Pelog Lima is realized due to the triggering combination of Leres, Rempeng, Greget Urip, and Sarèh Sumèlèh work models in each composition parts. Gendhing garap aspects as laras triggers have been formulated based on gendhing garap function analysis, which is combined with the opinions of board of jury panel as Javanese karawitan experts as well as the respondents. The compliments expressed by the viewers after watching the show either directly or through YouTube are the original expressions on the aesthetic senses which have been experienced by the viewers.

\section{Conclusion}

Laras is a type of sense, atmosphere, or a deep impression of beautiful, delicious, comfortable, and entirely containing elements of mat, lega, betah, adhem, ayem, tentrem, jinem, sengsem, marem arising from interactive events which processes are made dynamically, correctly, clearly, fairly, evenly, in balance, unison and integrated manners in forming the perfect equilibrium centers called synchronized points. The presence of gendhing is triggered by the application of laras work model, technique, pattern, and wiled play as well as gendhing elements played correctly; rempeg, gendhing elements are made dynamically, evenly, in balance, unison, and integrated manners; greget-urip, gendhing garap expressed in full concentration, spirit, and understanding, and sarèh-sumèlè gendhing garap performed quietly, patiently, not in a hurry based on the mastery of mature work device aspects.

\section{References}

Alfian, T. I. (2003). Dimensi Teori dalam Wacana Ilmu Pengetahuan. Yogyakarta: ISI Yogyakarta.

Benamou, M. (1998). Rasa in Javanese Musical Aesthetics. Dissertation. Michigan: The University of Michigan.

Brinner, B. (1995). Knowing Music Making Music Javanese Gamelan and The Theory of Musical Competence and Interaction. Chicago: The University of Chicago Press.

Budiarti, M. (2013). Konsep Kepesindenan dan Elemen-elemen Dasarnya. Harmonia: Journal of Arts Research and Education, 13(2), 147-156

Hastanto, S. (2009). Konsep Pathet dalam Karawitan Jawa. Surakarta: ISI Surakarta Press.

Hastanto. (2009). Penelitian PengertianKonsep Embat dalam Karawitan Jawa. Paper presented on conference. ISI Surakarta, Surakarta.

Marianto, M. D. (2011). Menempa Kuanta Mengurai Seni. Yogyakarta: ISI Yogyakarya.

Martapangrawit. (1975). Pengetahuan Karawitan. Surakarta: ASKI Surakarta.

Perlman, M. (1993). Unplayed Melodies Music Theory in Post Colonial Java. Dissertation. Wesleyen: Wesleyen University.

Rohidi, T. R. (2011). Metodologi Penelitian Seni. Semarang: Cipta Prima Nusantara

Rustopo. (2000). Bangun Jatuh Industri Rekaman (musik) Gendhing Karawitan Jawa. Jurnal Ilmu dan Seni, 2(2).

Sedyawati. (2006), Budaya Indonesia Kajian Arkeologi, Seni, dan Sejarah. Jakarta: Raja Grafindo Persada.

Soetarno, Sunardi, \& Sudarsono. (2007). Estetika Pedalangan. Surakarta: CV Adji.

Sukamso. (1992). Garap Rebab, Kendhang, Gendèr, dan Vokal dalam Gendhing Bondhet. Research Report. Surakarta: STSI Surakarta. 
Sumarsam. (2003). Gamelan, Interaksi Budaya dan Perkembangan Musikal di Jawa. Yogyakarta: Pustaka Pelajar.

Juslin, P. N. (2013). What does music express? Basic emotions and beyond. Frontiers in Psychology, 4, 596.

Merrieam-Webster. (N.d.). Concept | Definition of Concept by Merriam-Webster. Retrieved June 6, 2017, from https:/ / www.merriam-webster. com/dictionary/concept

Suharto, S. (1991).Bayangan Nada sebagai Materi bagi Pembelaja Musik Pemula. Media FBS Unnes, 18

Suharto, S. (2000). Peran Seni dalam Pengoptimalan Fungsi Otak. Lingua Artistika, 23(27),134-142

Suharto, S. (2009). Jurnal Seni Kelas Dunia. Gagasan Unnes.ac.id

Suharto, S. (2013). Suara Emas dari Unnes

Sinden Contest (Sinden Idol).FLV - YouTube. Retrieved June 6, 2017, from https://www.youtube.com/ watch? $\mathrm{v}=4 \mathrm{Cb} 7 \mathrm{nw} 1 \mathrm{tfhU}$

Suharto, S. (2016). Banyumasan Songs As Banyumas People's Character Reflection. Harmonia: Journal of Arts Research and Education, 16(1), 49-56.

Supanggah, R. (2002). Bothekan Karawitan I. Jakarta: MSPI.

Supanggah, R. (2009), Bothekan Karawitan II: Garap. Surakarta: PPS ISI Surakarta \& ISI Surakarta Press.

Suwardi, A. L. (2000). Teknik Tabuhan dan Tutupan Gender. Surakarta: STSI Surakarta.

Waridi. (2002). Jineman Uler Kambang: Tinjauan dari Berbagai Segi. Dewa Ruci, 1(1), 126-130.

Widada. (2001). Kamus Basa Jawa (Bausastra Jawa). Yogyakarta: Kanisius.

Winter \& Ranggawarsita. (1994). Kamus Kawi-Jawa.Yogyakarta: Gadjah Mada University Press.

\section{Respondents}

Darsono, 60 years, an expert of Javanese karawitan vocal works, Indonesian Arts institute (ISI) of Surakarta

Supadmi, 63 years, an expert ( $m p u)$ of Javanese karawitan sindhènan vocals, Surakarta

\section{Glossary}

Abon-abon : a sindhènan vocal part which uses meaningless texts

Adhem : cool

Alok : unimpeded toneless shouting vocal

Andhegan : gendhing stops at a moment before accent.

Ayem : at peace

Ayu kuning : a playing pattern type of gendèr barung

Balungan

gendhing : gendhing song framework, sketch, or outline

Betah : feeling at home, happy, comfortable

Cakepan

Céngkok

: vocal song lyrics

: playing pattern; gendhing song length unit; Karawitan style

$\begin{array}{ll}\text { Celuk } & \text { : a vocal song to start gendhing } \\ \text { Clempung } & \text { : a plucked instrument larger than }\end{array}$ sitar

Ciblon : a Javanese drum type instead of bem, sabet, and ketipung

Demung : a metal plate instrument of the largest balungan group

Dhadha : a reference to tone telu (three) commonly called $l u$ with numerical symbol 3

Dhebyang

dhebyung

: a playing pattern type in gendèr

barung

Dualolo : a playing pattern type in gendèr barung

Ela-élo : a playing pattern type in gendèr barung

Embat : a jangkah pattern variant in larasan gamelan

Engkuk

Gatra

: pencon's structural metal instrument as kemong's partner

: Musical unit consisting of four sabetan balungan.

Gambang : wooden plate instrument of wingking work group

Gamelan : a set of musical instruments in karawitan

Gangsaran : a form of small size Javanese gendhing

Gantungan : a playing pattern type in gendèr barung

Gemakan : a playing technique type in slenthem

Gembyang : octave, a playing pattern type in bonang

Gendèr b

arung : a metal plate instrument of ngajeng work group

Gender

penerus

Gendhing

: a metal plate instrument of wigking work group karawitan musical composition posessing mérong and inggah part.

Genjotan

: a playing technique type on demung and saron.

Gérong : (male) vocalist performing gérongan vocal type. : gamelan

Gongsa

Gong
: the biggest metal instrument of pencon's structural group 
Grambyangan: a short composition played by the earliest instruments

Gregel : a set of tones played in rapid tempo

Greget : full of energy or spirit

Gugukan : a playing pattern type in gendèr barung.

Gulu : a reference of tone loro read ro with a numeric symbol 2

Irama : a gatra widening and narrowing

Jarik kawung : a playing pattern type in gendèr barung

Jinem : a very comfortable feeling

Jineman : a Javanese gendhing type emphasizing on vocal work

Kacaryan : a playing pattern type in gendèr barung

Kadhal mènèk: a playing technique type in rebab

Kawahan : a kendang playing pattern to mark accent

Kawilan : a playing pattern type in kendang ciblon

Kecekan : a playing technique in sitar, celempung, demung, and saron

Kecèr : toneless metal plate instrument

Kempyang : pencon's metal instrument as kethuk's partner.

Kempyung : Two tones with two-tone distance played together

Kemong : pencon's metal instrument as engkung's partner.

Kendang : a double-sided membrane instrument

Kenong : a big metal instrument of pencon's structural group

Keplok : applause

Ketawang : name of small-size karawitan composition form

Kethuk : pencon's instrument as kempyang's partner

Kinthilan : a playing pattern type in saron 1 and saron 2

Kutuk kuning : a playing pattern type in gendèr barung

Lancaran : name of small-sized karawitan composition form

Laya : gendhing performance speed at the same irama (rythm).

Lega : Relieved, satisfied

Leres : correct, acurate, proper

Mat : delicious

Nduduk : a playing pattern type in gendèr barung

Ngaplak : kendang ciblon playing pattern performed right before gong

Ngelik : gendhing's high tone composition part

Ngicrik : a playing technique type in rebab

Nut kepatihan: karawitan notation using numeric symbols

Ora butuh : a playing pattern type in gendèr barung

Pangrawit : gamelan player
Panunggul : a reference of tone siji (one) read $j i$ with the numerical symbol number 1

Parikan : Javanese quatrain text form

Pathêt : sèlèh sense atmosphere in gendhing melodic flow

Peking : the smallest-size plate instrument of balungan group.

Pélog : type of Javanese karawitan musical scales in addition to sléndro

Pencon : a hollow round shape metal instrument with a pencu on its surface

Penembung : the biggest-size bonang like pencon instrument type

Pêthêtan : a playing technique type in gendèr barung

Pinjalan : a playing pattern performed with demung and slenthem

Plurutan : a playing technique type in rebab

Puthut gelut : a playing pattern type in gendèr barung

Rebab : a friction instrument in gamelan music

Rempeg : a sense of cohesive, unison, and integrated musical performance.

Ricikan :gamelan instrument

Sampak : a reference of small Javanese gendhing form.

Samparan : a playing technique type in gendèr barung

Saréh : patient

Saron : metal plate instrument of balungan group

Sarugan : a playing technique type in gendèr barung

Sekaran : a playing pattern

Senggakan : a vocal type played between the main vocals

Sengsem : fascinated

Sindhèn : female vocalist performing sindhènan vocal

Sindhènan : a rhythmic vocal in gendhing with wangsalan texts, parikan, and abon-abon

Siter : a plucked instrument other than clempung

Sléndro : a type of musical scales in Javanese karawitan other than pélog.

Srepeg : a reference of small gendhing form

Suling : a blowing instrument made of bamboo

Sumèlèh : a feeling after the burden is removed, relieved

Suwuk : gendhing ending performance

Tabuh : gamelan beating device

Tentrem : a very comfortable feeling

Thinthingan : gendèr barung playing to guide vocalist voice

Timpuh : a woman sitting way whose legs are folded down

Tumurun : a playing pattern type in gendèr barung

Ukelan : a playing technique type in gendèr barung 